\title{
Repressive inclusion
}

\section{John Reynolds}

To cite this article: John Reynolds (2017) Repressive inclusion, The Journal of Legal Pluralism and Unofficial Law, 49:3, 268-293, DOI: 10.1080/07329113.2017.1388100

To link to this article: https://doi.org/10.1080/07329113.2017.1388100

曲 Published online: 16 Nov 2017.

Submit your article to this journal

Џ Article views: 84

View Crossmark data ¿ 


\title{
Repressive inclusion
}

\author{
John Reynolds \\ Department of Law, National University of Ireland, Maynooth, Ireland
}

\begin{abstract}
This article examines the relation between emergency legal doctrine and racial sovereignty in the context of Palestine. It theorises Israel's multifarious emergency modalities in a colonial present paradigm where traditional territorial colonisation is fused with modern security biopolitics. The Israeli juridical-security apparatus mimics European liberal legalism in presenting itself as generally accepting of human rights obligations, save in circumstances where particular illiberal measures are necessitated on security grounds. These measures, however, comprise a pervasive patchwork of emergency modalities that have penetrated all spheres of Palestinian political, economic and cultural life. The retention and application of the British Mandate-era Defence Emergency Regulations as well as the constitutional state of emergency have produced an emergency marked by longevity and racialisation. Furthermore, Israel has invoked the emergency derogation option under international treaties to claim the legality of measures such as mass internment without trial. I articulate these dynamics of legality, emergency and sovereignty in terms of "repressive inclusion": a racially contingent inclusion within - and repression by - the juridical order. This evokes the suffocating hold of racialised emergency legal structures. The consequences for Palestinian lives and bodies have been severe; the alienation of land and fragmentation of territory have been acute.
\end{abstract}

\section{ARTICLE HISTORY}

Received 20 April 2017

Accepted 2 October 2017

\section{KEYWORDS}

Emergency; exception; sovereignty; racialisation; Palestine; Israel

\section{Introduction: "A shattered, scattered space of exception"?}

The paradigm of an explicitly "colonial present" (Gregory 2004) remains prominent within settler colonial societies and colonial occupations that continue to chip away the edges of supposedly smooth "post-colonial" temporal and territorial parameters. The dynamics in Palestine/Israel today entail ongoing conquest, militarised hegemony and exploitation of resources by the Israeli state, in the context of racialised discourse and ordering. They also entail civilian settlement and plantation of occupied territory, and the imposition of direct political and legal institutional administration. While the ideological, legal and technological parallels between Israel's state security policies and the post-2001 "international state of emergency" (Jayasuriya 2008) are pronounced, Israel's relationship with the Palestinians remains distinct, evoking coloniser-colonised dynamics that are planted firmly in a struggle for control of the land. The categories and framings that were 
widely presented as new on the international plane after 2001 have long resided in Israel's legal landscape. The settler colonial and colonising Israeli state has, indeed, operated in a self-declared state of emergency since the first week of its formal existence in May 1948, spawning a complex matrix of emergency modalities that continues to burgeon. This is an emergency very much marked by both its longevity and its racialised anatomy. Palestine remains subject to colonial technologies of surveillance and securitisation that demarcate the colonised and the coloniser.

Israel's displacement of Palestine's people and violation of its places and spaces has, for Derek Gregory $(2004,136)$, splintered it into "a scattered, shattered space of the exception." I present this "shattered space" as a space heavily populated by law, however, rather than the legal vacuum that the idea of exception evokes for some. In the construction of a supposedly exceptional nomos in Palestine, law remains integral. It has spun a thick web of emergency powers, regulations, statutes, military orders and courts that continues to fan out. Every micro aspect of Palestinian life is enveloped by the suffocating hold of racialised emergency management. The emergency does not produce something novel or exceptional, but rather reproduces colonial nodes of governance through a proliferation of law and legal stratification.

At the same time, the image of a spatial zone at the bounds of law (most clearly manifested through the discharge of mechanised violence against the Gaza Strip) that Gregory's framing of exception evokes is apposite to aspects of Israel's relationship with the Palestinians. It is notable that Israel's representatives and apologists present the state as simultaneously normal and exceptional: a "normal" western liberal democracy, but one which is subject to unique threats to its state security. Critical analysis of Israel can mirror this imagery of parallel exemplarity and exceptionality from a different vantage point: Israel is in one sense exceptional as a state in which racialised privilege is legally encoded in a manner that undercuts democracy; in another sense it is an archetypal enactment of settler colonialism. This dyadic structure shapes "the oscillating relation between norm and exception that [in turn] constitutes the paradoxes of the Israeli-Palestinian relation" (Lloyd 2012, 60). Inherent in Israel's exemplary coloniality is the idea that racialised emergency rule is itself exemplary of settler colonialism.

This article examines the relation between emergency legal doctrine and racial sovereignty in the context of Palestine. It theorises Israel's multifarious emergency modalities in a colonial present paradigm where traditional territorial colonisation is fused with modern security biopolitics. The function of emergency law in the imposition and maintenance of sovereignty links Israeli practice vis-à-vis the Palestinians with other colonial encounters. The Israeli juridical-security apparatus mimics European liberal legalism in presenting itself as generally accepting of human rights obligations, save in circumstances where particular illiberal measures are necessitated on security grounds. These measures, however, comprise a pervasive patchwork of emergency modalities that has penetrated all spheres of Palestinian political, economic and cultural life. The consequences for lives and bodies have been severe; the alienation of land and fragmentation of territory have been acute.

\section{The law in these parts: settlement, sovereignty, emergency}

I articulate the dynamics of legality, emergency and sovereignty in Palestine/Israel as repressive inclusion. This framing suggests - perhaps in subtle contrast to usages of 
"inclusive exclusion" - a process whereby Palestinians are included within the Israeli juridical order but in a manner in which they are legally differentiated and discriminated against. They are denied the privileges afforded to Jewish nationals, while Israel's policies of segregation and apartheid are given institutional and legal grounding (Dugard and Reynolds 2013). The "provision" of law by Israel's civil authorities, and the extensive use of legal discourse and institutions - even if in decisionistic form - by the military authorities, speak to a form of inclusion. Here, the net effect is that of a discriminating and repressive inclusion; one that is racially contingent. This conceptualisation evokes the suffocating hold of racialised emergency legal structures on Palestinian life, and provides a fuller explanation than that of exclusion. It also applies (in different ways through different legal statuses and techniques, but with a common logic) to Palestinian citizens of Israel as well as to Palestinians living under occupation in the West Bank and Gaza. Intermittent crises and moments of exception are bridged and transcended by mundane everyday legal techniques of control and oppression.

Emergency modalities are central to this slow violence of the law. Amidst the array of emergency decrees promulgated by Israel's executive, legislature and military, the Palestinian space emerges as a realm saturated by legal regulation. It is necessary, then, in the Palestinian case as much as broader colonial contexts, to explore the extent to which the state of emergency and related mechanisms are pivotal to the construction of a juridical order that itself inscribes conquest, occupation and settlement. The routine, everydayness of the violence - physical, psychological and administrative - of segregation and occupation reveals "the banality of the colonial present" (Gregory 2004, 16). The filtering of this violence through (normalised colonial emergency) law aims to legitimise its performance for both external and internal audiences. Israeli actions are justified in regulations, statutes, commissions of inquiry and judgments. International lawyers may argue as to whether those actions and legal regimes actually uphold the "rule of law," comply with the strictures of the Geneva Conventions, or are permissible derogations from international human rights covenants, but they remain within the space of a juridical order.

In many ways, law is itself the connective tissue binding the twin colonial logic of fear and dispossession that haunts the Palestinian national and social condition. Law and legal narratives are indeed central to the story of the colonisation of Palestine. Early Zionist settlement was facilitated by particular instruments of international law. This settlement then became the basis for the assertion of sovereignty through the establishment of the Israeli state and, subsequently, that state's annexationist policies in the West Bank - most notably and legalistically in respect of East Jerusalem. To preserve this expanding sovereignty, the international legal doctrine of self-defence has routinely been invoked by Israel. ${ }^{2}$ Conquest, that is, by self-defence. Emergency laws and powers are intimately connected to this offensive defence. Emergency doctrine is an integral weapon in the arsenal with which occupation is waged. It is instrumentalised to foment and sustain fear so as to underwrite the measured tightening of the grip on Palestinian land, movement and thought. Settler colonial policy in Israel is, as it has been elsewhere, performed through law.

The settler colonial analytic is, as Brenna Bhandar and Rafeef Ziadah (2016) put it, "an essential lens to understand the myriad forms of dispossession experienced by Palestinians from the late nineteenth century," and one that allows us to historicize the colonization of Palestine as a process that began long before 1948. ${ }^{3}$ Jewish migration to Palestine, as it began on a collective scale in the early 1880s following the establishment of the first 
colony in 1878, was quickly followed by the escalation of Zionist discourse aimed at the creating the ideological framework of a Jewish state in Palestine. By the time of the "Second Aliyah" of 1904-1914, it was clearly constituted as a settler colonial movement whose constituents sought no part in the existing polity in Palestine, but rather aimed to establish their own sovereignty (see, e.g. Shafir 1989). In the idiom of Zionist ideology, the term "settlement" (yishuv) carries a powerful resonance. Its roots lie in the phrase Yishuv Eretz Yisrael ("settlement of the land of Israel"), and the pre-state Jewish community in Palestine is still referred to in Hebrew as the Yishuv. For the Zionist movement, settlement is inextricably linked to the procurement of sovereignty, an essential precursor to the attainment of statehood and title to territory. This epitomises settler colonial ideology, and illuminates the rationale underpinning Israel's ongoing "settlement" of the West Bank.

While anchored by certain cardinal features, every colonial encounter and every settler colonial process has its own defining idiosyncrasies. Zionist settler colonialism is somewhat distinct in that in did not have one specific "mother" nation-state in Europe from which the settler population and other forms of logistical and political support were drawn. It was based, instead, on the "more diffuse but no less potent 'Western civilization' of which Zionism has believed itself representative since the earliest days of the colonisation of Palestine" (Lloyd 2012, 68). In the context of the Balfour Declaration and the League of Nations Mandate for Palestine, settler sovereignty developed under the protective guard of British administration. The emergence of the Israeli state from that embryonic sanctuary was a markedly less anti-colonial moment than other decolonisations throughout Africa and Asia that came soon afterwards.

Instead, a spiral of colonialisms curls through the Israeli self-determination project, connecting early Zionist settlement with British colonial foreign policy, the League of Nations Mandate, the role of the United Nations in legitimising Zionist claims to sovereignty via settlement (in the 1947 partition plan and subsequent recognition of Israel's independence), and Israel's continued colonisation of the West Bank today. These connections are woven deep into the fabric of political and legal discourse in Palestine, and suggest that international law and institutions, far from remaining above the political fray, are profoundly compromised by their engagement in the whole affair. Palestine emerges as a victim of the coloniality in which international law's heritage is rooted. We can identify a "train of legal instruments which sweeps through the last century from the Balfour Declaration onwards through the League of Nations Mandate, the UK's Order-inCouncil, the United Nations Partition Resolution, Security Council Resolution 242, the Oslo Agreements and the Quartet Road Map" to demonstrate that international law "has constructed the Palestinians as peripheral," and that "[1]aw has played a major role in pushing Palestine and the Palestinians to the political and territorial margins" (Strawson 2005, 2).

The language of the early twentieth century international legal instruments - the "Jewish national home" promised in the Balfour Declaration; the commitments made in the League of Nations Mandate to "facilitate Jewish immigration" and "encourage, in cooperation with the Jewish Agency ... close settlement by Jews of the land"; the reduction in that same text of Palestine's 90\% Arab majority to "other sections of the population" and "existing non-Jewish communities" - set the tone for the marginalisation of the Palestinians. The elision of Palestinian identity by the League of Nations and the British Mandate in particular contributed to the fostering of conditions in which the dispossession of 
Palestinian land would occur. ${ }^{4}$ From a pre-Mandate articulation of the "determination of the Jewish people to live with the Arab people on terms of unity and mutual respect and together with them to make a common home into a flourishing community," Zionism was able to evolve into an increasingly exclusionary form of Jewish nationalism under the British protectorate. Zionist settlement in Palestine proliferated during the League of Nations era, with the Jewish population rising from 80,000 in 1917 to 390,000 in 1939; "the context of the Mandate created the framework in which Jewish political and legal identity developed. It was the Mandate that gave Jews the first quasi-national political institution with legal powers - the Jewish Agency" (Strawson 2002, 376), which would subsequently form the nucleus of the Israeli state. ${ }^{6}$ The UN's 1947 partition plan and recognition of Israeli sovereignty amounted to a legitimation of settler colonial policy and an acceptance of the idea that the territory of Mandate Palestine was legally disputed.

Since then, international law has shown itself sufficiently indeterminate ${ }^{7}$ to have been harnessed and sculpted by Israel's military legal advisors and Supreme Court judges. Law is invoked in Israel to endorse colonial policies and, among other things: to deny the existence of any sovereign claims to the West Bank and Gaza concomitant or subsequent to their status as British colonial territory and prior to their colonisation by Israel; to discard the "non-humanitarian aspects" of humanitarian law; to afford privileges and protections to settlers; to justify the construction of the Wall and its associated colonising infrastructure in the West Bank; to sanction targeted killing policies (see, e.g. Gunneflo 2016); to legislatively categorise Palestinian fighters as "unlawful combatants" and deprive them of the protections afforded to either civilians or combatants; and to legitimise the siege of Gaza and the launching of aerial bombardments and ground incursions in "self-defence." As has been noted, "the historical record shows that it can be convenient for the hegemon to have a body of law to work with, provided that it is suitably adapted" (Vagts 2001, 845). The attention paid to both domestic and international law by the Israeli military is politically significant.

Ra'anan Alexandrowicz's 2011 documentary on the Israeli legal apparatus as it relates to the occupied territories, The Law in These Parts, provides lucid insight into the role of Supreme Court and military court judges in the administration of the occupation, and into the function of law as an instrument for settler colonial ends. Alexandrowicz presents "law as an issue of language; its inefficacy and its arbitrariness, its brutality." It is a language that most people do not understand, but also one whose meaning is contingent on its speaker. In the Israeli-occupied territories, law serves as an alibi for power rather than a constraint on it, and as such has been emptied of any meaningful relation to concepts of justice. One particularly revealing passage in the film relates to legal justifications for the seizure of Palestinian land in the West Bank in pursuit of settlement construction. Former military judge and legal advisor to the West Bank military command, Alexander Ramat, recounts how Ariel Sharon (Minister for Agriculture and head of the government's settlement committee at the time) summonsed the Israeli military lawyers for a meeting within minutes of the Elon Moreh judgment ${ }^{8}$ being handed down by the Supreme Court in October 1979. In that case, Palestinian land-owners Azat Muhamed and Mustafa Dweikat had argued that the military seizure of their (and their neighbours') privately owned land ${ }^{9}$ occupied in June 1979 by a settler group in an operation directed by Sharon (Weizman 2007, 100) - for the purposes of Israeli civilian settlement had been illegal. Preceding Supreme Court jurisprudence had upheld similar requisitions of private land as 
permissible under the laws of occupation, on the grounds that the civilian settlements and infrastructure concerned performed valid and essential military and security functions. ${ }^{10}$ As Eyal Weizman $(2007,105)$ explains:

Between 1967 and 1979, on the basis of the exceptions of "temporariness" and "security" the government issued dozens of orders for the requisition of private land in the West Bank. When called upon to do so, the government and the military demonstrated their claim for the pressing security needs by inviting expert witnesses, usually high-ranking military officers or the Chief of Staff himself, to testify that a particular settlement dominated a major artery, or another strategic location, that it could participate in the general effort of "regional defence", or in the supervision and control of a hostile population. As long as this claim was maintained, the High Court of Justice rejected all petitions of Palestinian landowners and accepted the government's interpretation of the term "temporary military necessity".

The concepts of temporariness and security are embedded in the idea of the state of emergency, as well as that of occupation. In the Elon Moreh case, such defences against the claim of unlawful expropriation were less than coherently presented by the state. Then Israeli military Chief of Staff, Refael Eitan, couched the necessity of the settlement in terms of "regional defence" in the hypothetical event of an inter-state war in the region, rather than any specific or immediate security threats within the West Bank. At the same time, the Gush Emunim movement involved in settling the land around Dweikat's village of Rujeib - supported by elements of the Likud government that had come to power in 1977 - was unreserved about the permanence of their intentions. They made no claims to the settlement serving mere temporary or security purposes. One of the settlers, Menachem Felix, made the point clear in his testimony to the Court:

Basing the requisition orders on security grounds in their narrow, technical meaning rather than their basic and comprehensive meaning as explained above can be construed only in one way: the settlement is temporary and replaceable. We reject this frightening conclusion outright. It is also inconsistent with the government's decision on our settling on this site. In all our contacts and from the many promises we received from government ministers, and most importantly from the prime minister himself - and the said seizure order was issued in accordance with the personal intervention of the prime minister - all see Elon Moreh to be a permanent Jewish settlement no less than Deganya or Netanya. ${ }^{11}$

Presented with such overtly contradictory positions to the discourse of "temporary" security needs, the Supreme Court ordered the authorities to return the land in Rujeib to its owners, prompting Sharon to immediately set about devising an alternative legal premise for the project of seizing and settling Palestinian land. ${ }^{12}$ At the meeting called by Sharon in the wake of the judgment, Ramat offered the idea of reviving the concept of mawat land ("dead" or "unused" land) from nineteenth century Ottoman agrarian land law. According to this doctrine, land lying a certain distance outside a given village, even if belonging to someone, is only owned temporarily as long as that owner cultivates it. If it is not cultivated for three consecutive years, it is considered "dead land" belonging to no one, and reverts to the empire. ${ }^{13}$ Satisfied that this could serve the settlement project's purpose, Sharon gathered a team of lawyers and geographers and set about identifying, mapping and registering uncultivated land using aerial photometry. Elon Moreh was established on an alternative site on this basis, and throughout the West Bank swathes of land were declared state land by the regional military command. A number of techniques were then constructed around this policy, such as the reduction of water quotas to 
Palestinian farmers to curtail their capacity to cultivate land. ${ }^{14}$ The expropriation through re-categorisation was upheld by the Supreme Court, and the scale and pace of settlement construction escalated from the late 1970s. As Weizman $(2007,108)$ notes, therefore:

\begin{abstract}
Although the liberal press celebrated the Elon Moreh ruling as a victory over the Likud government, it later became clear that this ruling was nothing but a Pyrrhic victory. Not only was Elon Moreh established on an alternative site; indeed, for whoever wished to read it, the ruling's wording itself indicated alternative methods of access to land. The court confirmed that future access to land in the Occupied Territories for the construction of settlements would be permitted on public land entrusted to the custodianship of the military power, and added that if the state adheres to this principle, the court would no longer interfere in its future settlement efforts.
\end{abstract}

The Supreme Court did this through accepting the seizure of huge quantities of state land, including private Palestinian land recast as state land, ${ }^{15}$ as well as by holding that the legality of the settlements themselves was a "political" question and as such not justiciable before the courts. ${ }^{16}$ Former Chief Justice Meir Shamgar claims that the developments initiated by the Israeli military legal professionals and the decisions taken by the Supreme Court had no bearing on the manner in which Israel's land and settlement policies proceeded in the occupied territories, arguing there was "no indication that the steps taken by the Court are connected to this phenomenon.... This is a political phenomenon, not connected to the Court." ${ }^{17}$ Alexandrowicz plainly exposes this constructed law/politics binary as a false and implausible separation.

Law was very much part of the political discourse and dynamic of settlement. The "dead land" concept finds obvious analogy in the common law doctrine of terra nullius, used to great effect in the colonisation of Australia and North America through the acquisition of land marked not by emptiness per se, but by an absence of "civilised" society capable of exercising sovereignty. It also evokes a liberal imperial theory of property rights, which justified the non-consensual nature of colonial dominion and the dispossession of indigenous peoples who were not cultivating the land in question. Settlers who did mix their labour with the land to improve it gained rights to the land. Once such rights had been established, any native attempts to regain the land could be put down with force. As Alexandrowicz's narration highlights, with Israel's military occupation now succeeding Ottoman and British rule, "what the IDF [Israeli military] says goes ... the regional commander is now the empire." This conjures up a distinctly Lockean understanding of sovereign prerogative.

Within the broader legal discourse in Israel, the direct and concrete legacy of British colonial emergency measures occupies a central position. Israel remains in a perpetual state of national emergency and continues to apply the British Defence (Emergency) Regulations 1945 as part of the legal basis for policy as it relates to the Palestinians. In the construction of a supposedly exceptional nomos in Palestine, law remains pivotal. The state of emergency serves to frame the situation for both domestic and international consumption as one of defensive security rather than aggressive conquest. The deeper reality of institutionalised domination based on ethno-national lines, however, reinforces the notion of racialisation as a prominent component of the invocation of sovereign emergency power. As has typically been the case in colonial spaces, emergency powers are necessary to the preservation of sovereignty, serving as a bridge between the twinned pillars of liberal empire: conquest by force, and rule of law. The line connecting settlement and 
emergency powers can also be mapped. Settlement and cultivation act, for Zionism, as a precursor to the establishment of sovereignty. Emergency powers are subsequently discharged as an element of that acquired sovereignty in order to consolidate its supremacy over any competing claims. A plethora of emergency legal mechanisms converge to inscribe a form of control over the body, mind and territory of the colonised, and to suppress resistance to such control.

\section{Israel's emergency modalities}

The Mandate-era Defence (Emergency) Regulations constitute one element of Israel's broader, multifarious emergency legal regime. Within a region noted for prolonged use of emergency law as a governmental structure of authoritarian rule, ${ }^{18}$ Israel stands out as an exemplar of permanent emergency. In addition to the retention of the British emergency regulations, a state of emergency was proclaimed by the Provisional State Council on 19 May 1948 - in the first few days of the state's existence - and has persisted without interruption since then. This enables the executive branch to alter or suspend laws passed by the legislature. Some but not all elements of Israel's emergency modalities are dependent on this declared emergency. The Israeli legal system includes several mechanisms of emergency law that overlap, but exist independently of each other. The emergency jurisprudential situation is dense to the point of being described as "incoherent" and "convoluted" (Mehozay 2012, 137-138). Contrary to conceptions of this situation as the inadvertent accumulation of necessary threat-specific responses enacted at particular points in time, however, it is more revealingly understood as a concerted tool of governance whose structural ambiguity offers a convenient flexibility.

Emergency modalities in the Israeli legal order assume three principal legal forms. The Defence (Emergency) Regulations, as noted, remain on the law books of the land long after the departure of their original British authors. While framed in the lineage of colonial emergency doctrine, their subsequent application by Israel is not tied to the declaration of a state of emergency. ${ }^{19}$ Israel has itself constructed two further bases in law for extraordinary measures. Specific administrative emergency orders or regulations can be promulgated by the executive branch of government, and are dependent upon a declared state of emergency. Primary emergency legislation enacted by the Knesset (Israel's parliament) can similarly be made contingent on the existence of a declared emergency, but may alternatively be worded to apply independently (Mehozay 2012, 140-141).

\section{The defence (emergency) regulations}

The Defence (Emergency) Regulations 1945 was the last version of the emergency code deployed by Britain in its administration of Palestine. It followed on from previous instruments that had been used suppress Arab revolt against foreign rule from the early 1930s: the Palestine (Defence) Order in Council 1931; the Palestine Martial Law (Defence) Order in Council 1936; the Emergency Regulations 1936; the Palestine (Defence) Order in Council 1937; the Defence (Military Courts) Regulation 1937; the Defence (Military Commanders) Regulations 1938; and the Defence Regulations 1939. Such texts had, between them, offered the typical panoply of emergency powers - censorship, curfew, closure, house demolition, movement restriction, detention without trial, deportation and 
land requisition - to the executive and military authorities. The Defence (Emergency) Regulations 1945 integrated much of what had been included in these instruments in a consolidated and more comprehensive form. The Regulations were used against both Palestinian Arabs and Jews in the post-war years before Britain abdicated its Mandate. They were condemned by Zionist leaders of the time as undemocratic and racist laws, to the point of being compared unfavourably to Nazi occupation standards. ${ }^{20}$

Following the establishment of the Israeli state, the Defence (Emergency) Regulations were adopted by Israel under Section 11 of the Law and Administration Ordinance 1948 (the first piece of legislation enacted by Israel's Provisional State Council). ${ }^{21}$ Proposals for the revocation of the Regulations (or their replacement by permanent legislation) were made in the Knesset in 1949, and on a number of occasions in the 1950s. Criticism voiced by Jewish-Israeli judges, legislators and religious figures routinely characterised the regulations as fascist and authoritarian. The context of this opposition was a small number of high-profile cases of administrative detention of members of Zionist paramilitary groups. In a 1951 Knesset debate over whether the provisions of the Regulations providing for detention without trial ought to be extirpated from the Israeli legal system, then opposition leader Menachem Begin challenged Foreign Minister (and, at the time, acting Prime Minister) Moshe Sharett's defence of administrative detention and his contention that "law is law":

Not so! There are tyrannical laws, there are unethical laws ... And an unethical law is also an illegal law. The detention is therefore illegal, and your order is arbitrary. ${ }^{22}$

Notably, however, the Regulations had also emerged by 1950 as the legal basis for the system of military government imposed on the predominantly Palestinian Arab regions within Israel. As the threat of Jewish attacks against the state dissipated, the racialisation of the Regulations intensified through their use against Palestinian citizens of Israel. By the end of 1948, the main Arab population centres inside what had materialised as Israel's de facto borders - most of which had been mapped outside of Israel's borders in the UN partition plan - were effectively under military rule. Five military governorates were created: Jaffa, Ramle-Lod, Nazareth, the Western Galilee, and the Negev. Throughout 1949, these areas were classified as occupied territories, before an integrated system of military government was established in 1950 under the direction and coordination of the Ministry of Defence. This form of military rule of the Palestinians within Israel continued until 1966, with the Defence (Emergency) Regulations as its primary legal framework. As such, a territorial zone of emergency was carved out within Israel in a racially contingent manner, based on the demographic make-up of the region concerned. For Edward Said (1979, $36,105)$, the implications were clear:

These laws were openly racist in that they were never used in Israel against Jews. When Israel retained them after 1948 for use in controlling the Arab minority, they forbade Arabs the right of movement, the right of purchase of land, the right of settlement, and so forth. Under the mandate the regulations were regularly denounced by the Jews as colonial and racist. Yet as soon as Israel became a state, those same laws were used against the Arabs. ... Until 1966, the Arab citizens of Israel were ruled by a military government exclusively in existence to control, bend, manipulate, terrorize, tamper with every facet of Arab life from birth virtually to death. 
Israeli scholars acknowledge that the regulations were used almost exclusively against Arabs (Kretzmer 1990, 116, 128), and at the time the state comptroller held there to be "something improper" about a law like this being enforced against one particular group of the population. ${ }^{23}$ Said $(1979,103)$ asserts that the purpose underlying the application of stringent emergency powers was "to pay that wretched [Palestinian population] for its temerity in staying where it did not belong," seeing it as entwined with the "Judaisation" of those parts of Israel that retained an Arab majority. The discourse of Israeli leaders during this period offers little to dispute that claim, with a racialised vision of the state very much to the fore. David Ben-Gurion's 1960 speech to the World Zionist Congress is a case in point, eliding the binational character of the country's population:

In Israel there are not two spheres.... Here everybody is both Jewish and universal: the soil we walk upon, the trees whose fruit we eat, the roads on which we travel, the houses we live in, the factories where we work, the schools where our children are educated, the army in which they are trained, the ships we sail in and the planes in which we fly, the language we speak and the air we breath, the landscape we see and the vegetation that surrounds us-all of it is Jewish. ${ }^{24}$

While military rule and the Defence (Emergency) Regulations are most commonly associated with the security provisions mandating restrictions on liberty through powers of arrest, detention and curfew, other aspects of the Regulations that have had a more profound structural impact on relations with the Palestinians. Ben-Gurion was frank about the primary function of the internal military government over Israel's Palestinian population: "the military regime came into existence to protect the right of Jewish settlement in all parts of the state." 25 The Defence (Emergency) Regulations were central to land and planning policies in Israel's formative years, underpinning an ideology of pioneering settlement that was as central within the new state as it had been in Mandate Palestine and would be in the post-1967 occupied territories. The regulations were used to expropriate large parcels of Palestinian land inside Israel through the creation of "closed" security zones. Under Regulation 125:

A Military Commander may by order declare any area or place to be a closed area for the purposes of these Regulations. Any person who, during any period in which any such order is in force in relation to any area or place, enters or leaves that area or place without a permit in writing issued by or on behalf of the Military Commander shall be guilty of an offense against these Regulations. ${ }^{26}$

From 1948, all of the Arab-Palestinian villages and towns in Israel, whether still inhabited or not, were declared by the military authorities as separate closed areas. This encompassed approximately $85 \%$ of the Palestinians on the Israeli side of the armistice line, with only those living in predominantly Jewish urban areas not directly affected (Quigley 2005, 106). Large tracts of land were closed by the military, with their inhabitants expelled or their owners denied access, and the land in turn confiscated by the state. Under Regulation 125, Palestinians were prevented from leaving their own village or town without a permit from the Israeli military authorities, even for the purposes of cultivating and harvesting their own lands, or of travelling to market towns to sell their produce. The Galilee area alone was divided into fifty-eight sectors for travel permit purposes. Applying for permits was a burdensome process, with requests often rejected. Palestinians residing or travelling without a permit - or with an expired permit, or a permit for a different route - 
were summarily fined or imprisoned, with recourse only to military courts. The Regulations thus operated to prevent Palestinian farmers from accessing and cultivating their own land. In a similar fashion to later developments in the occupied territories, the Minister of Agriculture was in turn mandated to classify closed-off Palestinian land as "uncultivated" and thus unprotected from expropriation (Nakkara 1985, 15-16). In his time as Director-General of Israel's Ministry of Defence, Shimon Peres (1962) made it clear that the fundamental value of the Defence (Emergency) Regulations was rooted not in immediate security concerns, but in facilitating Zionism's overarching goals: "By making use of Article 125, on which the Military Government is to a great extent based, we can directly continue the struggle for Jewish settlement and Jewish immigration." Regulation 125 was used in tandem with other mechanisms developed in the state's legal apparatus for the purposes of expropriating and acquiring Palestinian land, including the Abandoned Areas Ordinance 1948 and the Land Acquisition (Validation of Acts and Compensation) Law 1953.

Dispossession of Palestinians under this emergency infrastructure was sustained even where it was not condoned by the Israeli Supreme Court. Don Peretz $(1991,90)$ chronicles one example relating to the Arab-Palestinian population of the northern border village of Iqrit:

After surrendering to the [Israeli military] on 31 October 1948, the villagers were asked to leave for fifteen days because of "security reasons." Most left with only enough personal belongings for two weeks, but five years later the army still gave no indication that it would permit them to return. When the case was brought to the High Court of Justice in 1953, the court did not dispute the army's right to evacuate a population in times of emergency. However, questioning the procedures followed to prevent the return of the villagers after termination of the emergency, it ordered the army to permit the inhabitants to go home. The [Israeli military] responded by destroying most of the village and refusing to obey the court.

The Defence (Emergency) Regulations were used to extend the closure order in 1963 and again in 1972. Iqrit's expelled villagers went back to the Supreme Court with another petition in 1981, where it was this time held that their continued displacement was justified. ${ }^{27}$ The displaced Palestinians continued their campaign to return to their village. A Ministerial Committee appointed in 1993 found that there was no security imperative for the ongoing expulsion of those evacuated in 1948, and recommended a "compromise" solution whereby approximately $10 \%$ of their original land would be restored to the villagers, on which each family would be entitled to build one house. In 2001, however, the Israeli cabinet issued a decision asserting that the same security concerns which had informed the 1972 closure under the Defence (Emergency) Regulations remained relevant, and the villagers were therefore prevented from returning. The Supreme Court deferred to this position and proposed that compensation be paid instead, a solution that was unacceptable to the displaced residents (Abu Hussein and McKay 2003, 85).

As the Iqrit case demonstrates, the Defence (Emergency) Regulations were retained inside Israel after the dissolution of military rule in 1966 and the transfer of government functions in the country's Arab areas to the state's civil authorities. Since then, the Regulations have continued to be used inside Israel, particularly in relation to land issues arising in border areas. Provisions of the Defence (Emergency) Regulations providing for the banning of "unlawful associations" (Regulations 84 and 85) and censorship (Regulations 
86-101) have been invoked in recent years to close Arabic-language newspapers, to ban Palestinian political parties and associations, and to disqualify their candidates from Knesset elections. $^{28}$

The use of the Defence (Emergency) Regulations inside Israel was most pronounced, however, during the crucial period of military rule up to 1966, as the state went about consolidating its demographic and territorial dominance. As Said $(1979,106)$ reminds us, "the best introduction to what has been taking place in the Occupied Territories is the testimony of Israeli Arabs who suffered through Israeli legal brutality before 1967." ${ }^{29}$ The legal tools were certainly carried across, with the Defence (Emergency) Regulations assuming a significant role in the legal architecture of the occupation. The racialised use of the Regulations continues to this day in the occupied territories through almost exclusive application to Palestinian residents. They provide the basis for a profusion of military orders covering administrative detention, home demolition, land seizure, curfew, deportation, and censorship. Defenders of Israeli security policy in this regard argue that the discriminatory application of the emergency regulations is between Israelis and non-Israelis purely on grounds of citizenship, not between Jewish-Israeli settlers and Arab-Palestinians on grounds of national or ethnic origin. Israel's prior targeted application of the emergency regulations towards its Arab citizens in the internal military government period, however, undermines this claim. The Defence (Emergency) Regulations have now been retained in the Israeli legal system for seven decades, playing on the licence granted by a supposed temporariness, but deeply entangled with the state's brand of racial sovereignty.

\section{Emergency measures under the declared state of emergency}

Pursuant to Section 9 of the Law and Administration Ordinance 1948, Israel was ushered into a declared and temporally indeterminate state of emergency from the first week of the state's formal existence. After more than forty years of the emergency as status quo, the governing legal framework was given a slight procedural makeover, with the authority to declare an emergency reconstituted in the 1992 Basic Law: Government, ${ }^{30}$ and subjected to a condition that the declaration "may not exceed one year." With the Basic Law proceeding to allow for unlimited renewals by parliament, however, the temporality of the emergency in effect remained indefinite. The Knesset has renewed the state of emergency every year thereafter without fail, meaning that Israel's national emergency has continued since May 1948 without respite.

A number of mechanisms are triggered by a declared state of emergency. The government is authorised to enact discrete administrative emergency regulations to circumvent "normal" constitutional guarantees. As such, while the legislature is responsible for declaring and renewing (normalising) the state of emergency, the executive has full discretion as to the nature of exceptional measures to be taken: "During a declared state of emergency, the government, and in urgent cases the Prime Minister alone, is authorized to enact emergency regulations for the defense of the state, public security, and the maintenance of supplies and essential services." Emergency regulations propagated under this authority can and do take supremacy over ordinary parliamentary legislation, prompting human rights organisations to decry the fact that bestowing such a mandate to the executive serves to "violate the principles of the rule of law and the separation of powers." 31 Executive emergency regulations have been imposed consistently from 1948. Many of them 
have supplemented Israel's land appropriation mechanisms under the Defence (Emergency) Regulations.

The Emergency Regulations (Absentees' Property) Law 1948 marks the genesis of Israel's "absentee property" doctrine. Under this doctrine, the land of an individual deemed an "absentee" can be confiscated by the state. This concept was moulded for the confiscation of property belonging to Palestinians that had been killed or forced to flee to neighbouring countries in 1948, but was applied even if, as "in many cases, the absentees were present - a legal fiction of Kafkaesque subtlety" (Said 1979, 105). Internally displaced Palestinians who were barred from returning to their homes, although still in Israel, were constructed as "present absentees." Significantly, in terms of racialisation, even if Jewish individuals could have ostensibly fallen within the definition (Kretzmer 1990, 102, 115), the Absentee Property doctrine has been implemented only against Arabs. An "absentee" is defined as any person owning land in Israel who is a citizen, national or resident of Lebanon, Egypt, Syria, Saudi Arabia, Jordan, Iraq, Yemen, the West Bank or Gaza, or who was a citizen of British Palestine but left the area that became Israel in 1948. These particular emergency regulations set the tone for the permanent legislation that superseded them in the form of the Absentees' Property Law 1950. Beyond the particular case of the "absent" Palestinian population - whether refugees outside the Green Line or internally displaced within - substantial tracts of land still remained in the possession of Palestinians who managed to stay and become citizens in Israel. The Israeli authorities thus devised additional emergency regulations aimed at accumulating further land. As early as the summer of 1948, a series of emergency orders were introduced to underwrite large-scale land transfers on purported state security grounds (Cohen and Cohen 2011, 56). The Emergency Regulations (Requisition of Property) Law 1948, for instance, was promulgated by decree to allow the provisional government to seize property. This was replaced and cemented by legislation enacted by the Knesset the following year. Significantly, the Emergency Land Requisition (Regulation) Law 1949 authorises land and housing requisition orders by the Israeli authorities not only for "the defense of the State, public security, the maintenance of essential supplies or essential public services" but also to facilitate "the absorption of immigrants or the rehabilitation of ex-soldiers or war invalids." ${ }^{32}$ As such, the legislation's thrust transcends security and defence necessities, and is explicitly linked to immigration and citizenship policies aimed at consolidating settler colonial domination. It is also important to note that land seizure under these orders was initially defined as a temporary requisition subject to certain time limitations which were eliminated in subsequent amendments, "effectively transforming the initial requisition into permanent expropriation" (Bisharat 1994, 517).

In a similar vein, a series of instruments relating to "waste" land put in train a process whereby Israel's Minister of Agriculture could assume control of "uncultivated" Palestinian land. This originated in the Emergency Regulations (Cultivation of Waste Lands) 1948, which was amended by the Emergency Regulations (Cultivation of Waste Lands) (Extension of Validity) Ordinance 1949 and the Emergency Regulations (Cultivation of Waste [Uncultivated] Lands) Law 1949, culminating in the Emergency Regulations (Cultivation of Waste Lands) Law 1951. In addition to being empowered to confiscate uncultivated land, the Minister of Agriculture is also mandated to assume control "of water resources and water installations which in his opinion are not sufficiently utilised." These measures have typically been used in conjunction with the Defence (Emergency) 
Regulations, whereby areas closed by the military authorities are subsequently confiscated by the Minister of Agriculture on the basis that they are no longer being cultivated. ${ }^{34}$

The Emergency Regulations (Security Zones) Law 1949 gives the Minister of Defence discretion to categorise areas (within ten kilometres of Israel's northern borders, and twenty-five kilometres of the borders in the south) as security zones that must be evacuated. This policy has been applied particularly in the Galilee region, the areas towards the Lebanese and Syrian borders, and around the Gaza Strip. Land acquired under this order has typically been sold or transferred to the Jewish National Fund, a para-state institution mandated to "acquire and develop lands in Palestine for the exclusive benefit of the Jewish people" (Dajani 2005, 18). Such measures, framed in a security discourse, function to feed into the deeper structural and demographic aspects of Israel's land policies.

The extensive grid of related emergency laws and regulations that are used in parallel and in mutually reinforcing ways is indicative of the state of emergency paradigm as a surface upon which settler colonial policies were legally inscribed from the outset in Israel. The torrent of emergency measures enacted for the purposes of land expropriation so soon after the state's foundation implies a degree of premeditation, and a continuity of pre-state Zionist policies and plans aimed at the conquest of Palestinian land. ${ }^{35}$ To insulate that conquest, and Jewish-Israeli domination of state institutions, a range of emergency mechanisms also operate to obstruct Palestinian participation in the political and social life of Israel and the region. The Emergency Regulations (Foreign Travel) 1948 [an instrument authorising the Minister of Interior to prevent Israeli citizens from travelling abroad "as he sees fit," and on the basis of secret evidence] and the Prevention of Infiltration (Offences and Jurisdiction) Law 1954 [an emergency law prohibiting travel, or assistance others in travelling, to a number of Arab states designated as "enemy states"] continue to be used to prosecute or impose travel bans on Palestinians. In 2002, for example, Palestinian member of the Knesset Azmi Bishara was indicted under these laws for helping Palestinian citizens of Israel to visit relatives in Syria. While his case was pending, the Knesset passed Amendment 7 to the Emergency Regulations (Foreign Travel) 1948, to remove diplomatic travel immunity from parliament members. From 2002, similarly, Sheikh Ra'ed Salah, a Muslim Palestinian religious leader in Israel, was prevented from travelling for annual pilgrimage by an emergency travel ban order issued by the Minister of Interior and upheld on security grounds by the Supreme Court. ${ }^{36}$

Although ostensibly tied to national security matters, Israel's emergency legal regime infiltrates a diversity of areas, often, as noted, without any discernible connection to perceived threats to the existence or security of the state. In addition to underwriting land expropriation and colonisation processes, dozens of sets of emergency regulations have been enacted in spheres spanning economic regulation, labour relations, shipping practices, civil registration, fire-fighting, trade and monetary issues. It has been noted that emergency regulatory powers under Section 9 of the Law and Administration Ordinance 1948 have been invoked, for instance, in "an almost routine fashion" since the Yom Kippur war in 1973 to bypass burdensome industrial dispute resolution processes "in situations where no special urgency was present or when other, less drastic means had been available" (Gross and Ní Aoláin 2006, 232-233, citing Hofnung 1996, 55-60, and Mironi 1986, 380 386). 
In addition to executive emergency decrees or regulations, statutory legislation-while enacted and amended by the Knesset in the same fashion as ordinary statutes - can also be framed in such a way that applicability is contingent upon the existence of a state of emergency. The Emergency Powers (Detention) Law 1979, for example, which enables administrative detention of residents of Israel, residents of territory occupied by Israel, and residents of other states, was framed so that it "shall only apply in a period in which a state of emergency exists in the State by virtue of a declaration under Section 9 of the Law and Administration Ordinance." This succeeded Regulations 108 and 111 of the Defence (Emergency) Regulations and grants discretion to the Minister of Defence to issue (and renew indefinitely) administrative detention orders where he or she "has reasonable cause to believe that reasons of state security or public security require that a particular person be detained." In the context of a perpetually renewed state of emergency, this ordinance effectively functions as an ordinary piece of permanent legislation, thus normalising the exceptional powers of detention without trial in the legal system. The fact that (leaving aside the continuing use of the law against Palestinian citizens of Israel) more than 800,000 Palestinians in the occupied territories - encompassing approximately $40 \%$ of the total male population - have been detained since 1967 under military order is testament to this normalisation (Addameer 2012,4).

Such deprivation of liberty en masse is ostensibly inimical to international human rights and fair trial standards. Upon ratifying the International Covenant on Civil and Political Rights in 1991, however, Israel submitted a formal notification stating that (since 1948) its security situation has constituted a public emergency within the meaning of the Covenant's derogation provision in Article 4 - that is, an existential "threat to the life of the nation." On this basis, Israel declared that it was suspending certain obligations under the Covenant and derogating from Article 9 (right to liberty). ${ }^{37}$ While expressing "concern" at Israel's reliance on the state of emergency in its periodic reviews of the state, the UN Human Rights Committee points to Israel's security and accepts that international law entitles states to derogate at their own discretion. ${ }^{38}$ As such, international law shows itself to be implicated in the perpetuation of Israel's emergency modalities. Characterisations of Israel's state of emergency as oppositional to international law thus present a somewhat simplified and idealised vision of the international legal system - a vision divorced from the field's own colonial legacy and its facilitation of emergency powers.

In its first review of Israel in 1998, the Human Rights Committee recommended that Israel reassess what was by then a fifty-year-old state of emergency "with a view to limiting as far as possible its scope." ${ }^{39}$ In its subsequent periodic review in 2003, the Committee remained concerned about the scope of Israel's emergency, while "welcoming the State party's decision to review the need to maintain the declared state of emergency and to prolong it on a yearly rather than an indefinite basis." ${ }^{\prime 0}$ As I have noted above, however, it had been clear from quite soon after the introduction of this change in the 1990s that it was essentially a cosmetic procedural reform that allowed for unlimited renewals and, as such, did not qualitatively affect the emergency's indefinite status. Israel has repeatedly told the Committee since this this time that it "has been inclined to refrain from extending the state of emergency any further [but that] the actual termination of the state of emergency could not be executed immediately, as certain fundamental laws, orders and regulations legally depend upon the existence of a state of emergency." ${ }^{41}$ In its 2010 and 2014 reviews of Israel, the Committee reiterated its concern at the continuing 
state of emergency and detention without trial of Palestinians, while continuing to acknowledge at face value "the ongoing legislative process regarding the future cancellation of the state of emergency." 42 Far from taking collective action or imposing sanctions on Israel, the international community of nations - particularly its Western powers - continues to covet and purchase the techniques and military technologies by which Israel maintains its colonial emergency rule (Lloyd 2012, 77).

On the domestic legal register in Israel, judicial challenges to both the Defence (Emergency) Regulations and the declared state of emergency have been brought at various points since 1948, resulting in the Israeli Supreme Court repeatedly stamping its imprimatur on the government and military authorities' use of emergency doctrine, thereby facilitating its normalisation.

\section{"Intent to regularise": emergency on trial}

One of the first cases brought before Israel's Supreme Court in 1948, arising from a request for revocation of an administrative detention order under the Defence (Emergency) Regulations 1945, involved a challenge to the validity of the British Regulations themselves in the nascent state's legal order. A minority dissenting opinion in the case was expressed by Justice Shalom Kassan. Justice Kassan argued that the regulations granting broad emergency powers to the executive and military authorities were undemocratic and inapplicable:

I cannot act and pass judgment in accordance with the defense regulations which are still on the statute book. Believing as I do that these laws are essentially invalid, I should not be asked to act against my conscience merely because the present government has not yet officially repealed them, though its members declared them illegal as soon as they were passed.... If the courts of the British Mandate did not cross these laws off the statute book, this court is honorbound to do so and to utterly eradicate them. ${ }^{43}$

The positivist majority decision of the Court, however, although expressing similar misgivings about the nature of the emergency regulations, held that the judiciary "must accept the regulations as they are, that is as valid, legal regulations." The outcome notwithstanding, a clear assumption that the government would annul the regulations in due course ran through the judgment. In a subsequent case of administrative detention of a Palestinian resident of Jaffa, the Defence (Emergency) Regulations were reaffirmed, although in this instance the detention order was annulled on procedural grounds. ${ }^{44}$ Petitions challenging the validity the Defence Regulations 1939 in the early days of Israel's existence were similarly rejected in formalistic terms by the Supreme Court, which refused to accept that the earlier Regulations had been implicitly repealed by the Law and Administration Ordinance 1948, or were inconsistent with the Declaration of the Establishment of the State of Israel. ${ }^{45}$ In essence, these judgments held that the promise of a new legal order based on equality, contained in Israel's declaration of independence, was not legally binding in character and did not invalidate arbitrary British colonial rules (Jabareen 2016; Masri 2017).

With the precedent asserted as to the Defence (Emergency) Regulations' standing, subsequent legal challenges sought instead to contest specific orders issued under the 
Regulations. In the El-Ard case in 1964, permission for the publication of an Arabic-language magazine in northern Israel was denied by the authorities on security grounds under Regulation 94. The association seeking to publish the magazine petitioned the Supreme Court, claiming the decision was unfounded and discriminatory. The Court indicated its tendency to defer to the executive and military on security matters and dismissed the petition, holding that Regulation 94 does not permit the Supreme Court to conduct an investigation of the facts and that its judicial review mandate is very limited under the Regulations. ${ }^{46}$ In the 1979 Al-Assad case, again arising from denial of a publication permit under Regulation 94, a Supreme Court majority this time rule that the Ministry of Interior should issue the permit. While not required to disclose evidence revealing the security concerns on which the denial had been based, the authorities in this instance had failed to fulfil their procedural obligations to provide other specified information to the Court. ${ }^{47}$ In a 1980 s case arising from very similar facts, the Supreme Court upheld the decision to withhold the permit on security grounds, as no such procedural mistakes on the part of the state arose. ${ }^{48}$

When the inherent problems in the doctrine of emergency are left to one side, two normative legal questions arise and remain in relation to Israel's declared state of emergency. The first is whether Israel's situation has, since 1948, continued to surpass the threshold constructed of an impending threat to the life of the nation that is sufficiently grave to warrant the imposition of an emergency legal framework. The second, given that successive Israeli governments have argued that the state of emergency has reached the necessary threshold, is whether the measures enacted in the state of emergency paradigm are a necessary and proportionate response to the perceived threat. These are legal issues that continue to plague a number of states, often marked by deficits of judicial supervision, and have preoccupied the case law and commentary of international human rights bodies. It was concerns over both of these questions that prompted legal activists to seek judicial review of Israel's declared state of emergency.

In 1999, the Association for Civil Rights in Israel (ACRI) submitted a petition to the Supreme Court against the legislature, challenging the constitutionality of the continued state of emergency, and seeking its annulment. The petition argued that the Knesset's persistent renewal and extension of a state of emergency has transgressed Israeli constitutional law and international legal norms, on the basis that Israel's security circumstances are not of such extraordinary status as to justify an extraordinary regime that subverts liberal understandings of rule of law and separation of powers. It was put forward that, in contrast to the purported intentions of the doctrine of emergency (here construed in a favourable light, detached from its own imperial history) to enable the implementation of urgent and necessary measures for a limited duration, Israel's state of emergency was permanent in time and unlimited in scope - and thus unlawful. ACRI further submitted that the declared emergency enabled the imposition of legislation and regulations that violate property rights, that unduly hamper free expression, association and assembly, and that contravene Israel's own Basic Laws.

As hearings proceeded following the outbreak of the second Palestinian intifada in 2000, the Supreme Court under former Chief Justice Aharon Barak suggested that the petition should be withdrawn given the exacerbated security situation. ACRI submitted an amended petition in 2003, which argued that even in a context of heightened threats to security the use of emergency powers should be minimal in time and scope, and that 
Israel's state of emergency declaration was still unfounded. The state's response (with the government of Israel now added to the Knesset as a respondent) claimed that repeal of the emergency would create a legal vacuum and deprive the authorities of the necessary means of suppressing threats to security. The government did emphasise its intention to move away from the (declared) state of emergency, and told the Court that it would continue to take steps to amend or replace legislation that is contingent on the existence of a formal emergency.

The Ministry of Justice provided the Court with ongoing notifications regarding the revocation and replacement of certain pieces of emergency legislation. The authorities presented the seemingly contradictory position that although a state of emergency continues to exist in fact, the state of emergency in law should be gradually phased out. What can be inferred from this is both a tacit acknowledgment that the factual situation does not justify the application of exceptional emergency legalities and, at the same time, a conflicting assumption that those exceptional legalities should be subsumed into the "normal" legal order over time.

The Supreme Court essentially agreed that while the continuing state of emergency is not ideal, it is a necessary "transitional" measure. Although acknowledging in regard to the legal framework that "the present situation must not remain unchanged," the Court has consistently framed the issue as a "complex and sensitive" one in which the authorities must be left with a generous margin of flexibility. ${ }^{49}$ In an interim decision of August 2006, the Court rejected ACRI's claim that Israel's situation was not in fact one of an ongoing state of emergency: "the war with terror is raging at full force, and it is impossible to disregard this." 50 At the same time, the Court noted that "the state of emergency has been exploited for statutory matters regarding which balanced legislation could have been enacted long ago." ${ }^{\text {1 }}$ The Court gave the respondents time to institute changes to civil legislation that was tied to the state of emergency, and by 2011 was satisfied that:

Progress has been made in the legislative processes. Part of the legislation that was contingent on the state of emergency was altered and amended, another part is in various stages of the legislative process, and there is an intent to regularise the remainder. ${ }^{52}$

Accordingly, in May 2012, after twelve hearings over the course of twelve years, the Court issued a twelve-page judgment (half of which comprises background information and summaries of the arguments) concluding that the petition had "run its course" and should be dismissed. ${ }^{53}$ Israel, according to the Court, continued to face a state of emergency, with the judgment asserting that "the winds of war have never ceased to blow, and unfortunately the situation remains relatively unchanged." ${ }^{24}$ Justice Rubinstein's opinion, on behalf of the Court, evokes Israel's siege mentality with lengthy descriptions of "the unending threats of our enemies from near and far." He quotes an extract from a ruling of the Court in the early 1980s - roughly the half-way point of Israel's state of emergency to date - from which it was clear that little had changed in the Court's approach in the subsequent thirty years:

As known, the state of emergency has lasted for over 30 years, and who knows how much longer it will continue. The fact that the state of emergency persists does, on the one hand, mandate the reduction of the emergency means the state employs to defend its existence so that, as much as possible, these means will not violate civil rights, but on the other hand, the continuing state of emergency, owing to well-known reasons and circumstances, points to 
the fact that it is difficult to compare the situation the State of Israel has been in since its foundation to that of any other state. ${ }^{55}$

Rubinstein maintains this narrative of Israeli exceptionalism in his depiction of a normal country (in that it is an "active democracy in which fundamental rights ... are safeguarded") that is not normal (in that it is subject to threats of a gravity faced by no other "normal" democratic country). ${ }^{56}$ The gauntlet thrown down by this "unique" situation thus challenges Israel to construct a juridical order that can respond to the exceptional threat without compromising the state's "normality." Rubinstein commends the state for its work to date in phasing out and replacing some emergency legislation, and highlights the need to continue extricating relevant security and anti-terrorism measures from a declared state of emergency; that is, to embed them instead within the "normal" legal system. Before and until this process is complete, it is not the place of the judiciary, the argument goes, to obstruct executive or legislative renewals of the state of emergency, nor to restrict the use of necessary powers that remain dependent on the declared state of emergency. Here, the Supreme Court's accustomed deference to the security agencies is apparent: "this court is not a substitute for the discretion of the authorised agencies." 57

\section{Racial sovereignty and hyperlegality}

In his reading of the proliferation of British anti-terrorism legislation enacted since the late 1990s, Nasser Hussain $(2007,515)$ describes a structural shift in the law away from traditional conceptions of emergency powers as reactive and temporary, towards an understanding of securitisation and security law as part of a larger, permanent "methodology of governance." Hussain emphasises certain mechanisms - the increasing use of (racialised) classifications of persons in the law, the emergence of intensely bureaucratic and administrative facets of emergency law, the use of special tribunals and commissions that contribute to "hyperlegality" at work. This hyperlegality typifies the contemporary security state and its "multiplication of laws and legal categories" (Lloyd 2012, 75). Related to this is the militarisation of policing and the seepage of armed conflict categorisations into domestic legal contexts via the counter-terrorism paradigm.

We can detect the emergence of a similar move in Israel in the process endorsed by the Supreme Court. This seeks to construct a framework of permanent extraordinary measures in order to preserve the control system over the Palestinians, as opposed to properly disentangling the web of emergency powers spun over the last six decades. The concept of hyperlegality is echoed here in descriptions of "Israel's military hyperregulation of everyday life [which] has been catastrophic for the Palestinians" (Makdisi 2008, 6). Here we may see how emergency powers can supply the framework for hyperlegality, in the context of the Israeli state's particular performance of racial sovereignty. In flowing from heavily racialised emergency and securitisation policies, hyperlegality in this paradigm (as opposed to generally prevailing intensifications of legalism in many jurisdictions) is vested with specific discriminatory structures and effects. The normalcy/emergency binary cedes part of the space of exception to a complementary domain in which the state of emergency is normalised in ordinary legislation ${ }^{58}$ and bolstered by "super-emergency" measures during large-scale hostilities. ${ }^{59}$ The non-contingent emergency laws will of course remain in place even if the state does follow through on its promise to phase out the 
official state of emergency, and the fluidity of Israel's disparate emergency legal mechanisms will continue to offer a vehicle for the execution of sovereign will.

This process of incorporating emergency powers into the ordinary legal system is underway and ongoing. In the summer of 2016, Israel's Knesset approved the Anti-Terror Law 2016, an extensive piece of counter-terrorism legislation that had been roundly criticised by human rights organisations from its early inception as a "draconian" move designed "to legally anchor the 'state of emergency' regulations ... and turn them into permanent legislation." 60 The law was advanced by Minister for Justice Ayelet Shaked, of the far-right Jewish Home party, as the enactment of her assertion that acts of - and support for - Palestinian violence "can only be vanquished through appropriate punishment and deterrence." ${ }^{\prime 1}$ This legislation applies specifically to Israel and occupied East Jerusalem, rather than the rest of the West Bank (where Palestinians remain governed by the separate military law system). It is an omnibus law that replaces a number of existing ordinances on terrorism and effectively re-imports a raft of provisions from the British Defence (Emergency) Regulations (which, as we have seen above, still apply in the occupied territories), as well as other temporary Israeli emergency/security regulations, into permanent Israeli criminal law. The legislation also introduces new crimes, including offences relating to public expressions of support or sympathy for groups designated as "terrorist" organisations, and expands the definition of "incitement" such that a link to any likely or actual act of violence is no longer necessary. Emergency style powers assigned to state authorities under the law include: sweeping arrest powers, detention without trial, use of secret evidence, suspension of habeas corpus, significantly increased criminal sentences, travel bans, control orders and computerised surveillance, as well as powers vested personally in the Minister of Defence to expropriate the homes and property of alleged members of banned organisations without requiring approval by the courts.

The law allows for a broad interpretation of what constitutes a "terrorist" organisation (it bears noting that most Palestinian political movements are already designated as such by Israel), and expands the definition of indictable membership of such organisations to include "passive members" who play no direct role in the organisation's activities. It casts the political activities and expression of Palestinians in Israel - including those of a social, humanitarian and charitable nature, particularly where they assist Palestinians in the occupied territories - as suspicious and susceptible to prosecution. As such, the Anti-Terror Law appears designed to persecute Palestinian citizens - marking them out as suspect "simply because they are Arab"62 - and to suppress their political activities in support of Palestinians living under occupation. ${ }^{63}$ The racial overtones of the legislation are clear both in itself, and within the context of the broader matrix of discriminatory law-making $^{64}$ of which it forms part. It is criticised on this basis by Palestinian and left-wing Jewish-Israeli members of the Knesset as "racist and totalitarian," ${ }^{65}$ with Ayman Odeh (head of the "Joint List," the alliance of the four predominantly Arab-Palestinian political parties in Israel) reading the law in its imperial context: "I see panic, the panic of the final stage of all colonialism worldwide. The panic of the French at the end of the occupation of Algeria. I see the panic of the Americans in the final phase of the occupation of Vietnam."66

Thus we return to the framing of the colonial present. Emergency modalities, as we have seen, have occupied a central place in the legal system of the colonised Palestinian space. Emergency doctrine's malleability and constructed exceptionality facilitates the forcible imposition of settler sovereignty, while its legality provides the necessary 
authorisation and veneer of legitimacy. It was, and is, an expression of law as a conduit for racialised hegemony, as the stage upon which scenes of dispossession are performed. The separate opinion of Chief Justice Beinisch in the Israeli Supreme Court decision on the state of emergency is candid in this regard: "The state of emergency declared by law is, to a large extent, the result of a political outlook." ${ }^{\text {67 }}$

\section{Notes}

1. See, e.g. Ophir, Givoni, and Hanafi $(2009,23)$. In this regard, much of the contemporary state of exception analysis in the context of Palestine (and beyond) draws on Giorgio Agamben's conceptualisations of exception and example as "inclusive exc'usion" and "exclusive inclusion" respectively. See Agamben $(1995,21,107)$. Agamben's formative work in this field can, however, be fairly critiqued for its lack of attention to race and colonialism. I address this further in Reynolds (2017, 36-46).

2. On such invocation of self-defence (and the acquiescence of large parts of the international community) as justification for its "Operation Cast Lead" offensive on the Gaza Strip, for example, see Reynolds (2010).

3. For a sample of the (renewed) engagement of Palestine scholarship with settler colonial studies, see the 2012 special issue on "Past is Present: Settler Colonialism in Palestine" in Settler Colonial Studies 2(1): 1-272.

4. "The Mandate marginalized the identity of the Palestinians, enshrining this in law. Whereas the Jewish population ... has a clear identity, the Palestinians ( $90 \%$ of the population) were merely 'non-Jewish' or 'other'. In this way, international legal discourse dispossessed a people of their identity which opened the way for others to dispossess them of their land" (Strawson 2002, 369).

5. Resolution of the Zionist Congress, September 1921.

6. The Jewish Agency, along with the World Zionist Organisation and other "para-state" institutions, remains central to the continuing colonisation of Palestinian land.

7. "[E]ven where there is no semantic ambivalence whatsoever, international law remains indeterminate because it is based on contradictory premises and seeks to regulate a future in regard to which even single actors' preferences remain unsettled. To say this is not to say much more than that international law emerges from a political process whose participants have contradictory priorities and rarely know with clarity how such priorities should be turned into directives to deal with an uncertain future.... It follows that it is possible to defend any course of actionincluding deviation from a clear rule-by professionally impeccable legal arguments that look from rules to their underlying reasons, make choices between several rules as well as rules and exceptions, and interpret rules in the context of evaluative standards. The important point I wish to make ... is not that all of this should be thought of as a scandal or (even less) a structural 'deficiency' but that indeterminacy is an absolutely central aspect of international law's acceptability" (Koskenniemi 2005, 590-591).

8. Dweikat v. Government of Israel, HCJ 390/79, judgment, 22 October 1979.

9. The fact that-going back to the Ottoman Land Law of 1858-much of the land in Palestine was marked as state land (miri) as opposed to privately owned land (mulk) had already been exploited by Israel, through the construction of an argument that state land in occupied territory is open to civilian settlement by the occupier (the purported temporariness of belligerent occupation notwithstanding). The British Mandate authorities had, for their part, modified the Ottoman laws to extend the reach of state land, effectively liberalising the land expropriation process, as well as making it easy for the military to seize any category of land for self-prescribed "security measures". See further Shehadeh (1993). In this case, the Israeli authorities had now moved to settling privately owned land in addition.

10. See, e.g. Abu Hilo v. Government of Israel [Rafah], HCJ 302/72, with Justice Vitkon explaining that although the seized land was designated for civilian settlement rather than military 
installations, the settlements "are in themselves, in this case, a security measure." See also Abu Hilo v. Government of Israel [Beit El], HCJ 258/79, with Justice Vitkon again: "In terms of purely security-based considerations, there can be no doubt that the presence in the administered territory of settlements - even 'civilian' ones - of the citizens of the administering power makes a significant contribution to the security situation in that territory, and facilitates the army's performance of its tasks."

11. Cited in B'Tselem $(2002,49)$.

12. It must be noted here that the Elon Moreh ruling did not have any bearing on the continued settlement of "state land" in the occupied territories, nor on prior requisition orders of private Palestinian land, which remained valid as far as Israeli law was concerned.

13. This process of expropriation of 'uncultivated' land through law was of course not unique to the Ottoman empire; analagous policies were implented elsewhere in different forms, for example, under British, French and Dutch colonial rule.

14. In just six years from 1979 to 1985 , the cultivated land in the West Bank was reduced by $40 \%$. Weizman (2007), 120.

15. According to Israeli organisation Peace Now's Settlement Watch team, by $2006,38.76 \%$ of the land on which settlements and settler industrial zones in the West Bank are located was privately owned Palestinian property (Etkes and Ofran 2006, 15). In February 2017, the Israeli legislature enacted the Settlements Regularisation Law (or Validation Law) to explicitly allow the state to expropriate private Palestinian lands in occupied territory for the purposes of settlement construction. Under the legislation, settlements built on private Palestinian land in the OPT can be "legalized" and "regularized" through retroactive expropriation, planning, and zoning regulations.

16. See, e.g. Bargil v. Government of Israel, HCJ 4481/91, judgment, 25 August 1993.

17. Quoted in Ra'anan Alexandrowicz, The Law in These Parts (2011).

18. For example: Syria 1963-2011; Egypt 1981-2012; Algeria 1992-2011.

19. Shetreet $(1984,183-184)$, cited in Gross $(2001,754)$ : "The Courts held that neither the provisions of the Mandate nor the language of, nor the qualifications contained in Section 11 excluded the reception of the Defense Regulations, including Regulation 11 dealing with administrative detention. The application of the Defense Regulations does not depend upon a proclamation of a state of emergency under Section 9 of the Law and Administration Ordinance 1948."

20. See, e.g. the speech of Yacob Shimshon Shapira (later Israeli Attorney-General and Minister for Justice), Jewish Bar Association, Tel Aviv, 7 February 1946, quoted in Ha Praklit (February 1946): "The regime established in Palestine with the publication of the Emergency Regulations is quite unique for enlightened countries. Even Nazi Germany didn't have such laws, and acts such as those perpetrated at Maidanek actually ran against the letter of German law." The Regulations were also condemned by the Jewish community in Palestine as indicative of a "police state" (Joseph 1948, 222).

21. On Britain's repeal of the Defence (Emergency) Regulations before relinquishing the Mandate in May 1948, and the subsequent legislative manoeuvring of the Knesset to profess that the regulations had not in fact been validly repealed, see, e.g. Quigley $(2005,103)$. Only Regulations 102 (which reinforced Britain's Immigration Ordinance 1941) and 107c dealing with illegal immigration were dropped so as to allow Jews who entered Palestine illegally under the British Mandate to remain in the new state.

22. Knesset Debates 9: 1807, 12 May 1951, quoted in B’Tselem (1992, 24). See also, e.g. Peretz (1991, 92).

23. State Comptroller's Report no. 9 (1957/58) 78, quoted in Quigley $(2005,104)$.

24. “Address by Prime Minister Ben Gurion” (New York Times, 52-53, 8 January 1961).

25. Knesset Debates 36: 1217, 20 February 1963, quoted in Quigley $(2005,109)$.

26. Government of Palestine, 1945. The Defence (Emergency) Regulations, Palestine Gazette no. 1442, Supplement no. 2, 27 September 1945, Regulation 125.

27. Committee of Displaced Persons from Iqrit, Rama and Others v. Government of Israel, HCJ 141/ 81 . 
28. For a number of examples, see Quigley $(2005,133-134)$.

29. Here, Said refers us to Jiryis (1976), al-Asmar (1978) and Zureik (1979).

30. Originally Article 49; now Article 38.

31. Adalah, "Information Sheet \#1: State of Emergency", submitted to the UN Human Rights Committee, 22 July 2003.

32. Emergency Land Requisition (Regulation) Law 1949, Article 3(a).

33. Emergency Regulations (Cultivation of Waste Lands) (Extension of Validity) Ordinance 1949, Schedule: Emergency Regulations Concerning the Cultivation of Waste Lands and the Use of Unexploited Water Resources, Article 17(a).

34. See further, e.g. Lustick $(1980,178)$ : “Typically the process works in the following way: An area encompassing Arab-owned agricultural lands is declared a 'closed area.' The owners of the lands are then denied permission by the security authorities to enter the area for any purpose whatsoever, including cultivation. After three years pass, the Ministry of Agriculture issues certificates which classify the lands as uncultivated. The owners are notified that unless cultivation is renewed immediately the lands will be subject to expropriation. The owners, still barred by the security authorities from entering the 'closed area' within which their lands are located, cannot resume cultivation. The lands are then expropriated and become part of the general land reserve for Jewish settlement."

35. A series of plans and guidelines were drawn up from 1944 by the Haganah, the pre-state Jewish militia in Palestine, designed to take control of territory for the Jewish state. This process culminated in Plan Dalet in early 1948, described as a "master plan for the conquest of Palestine" by Palestinian historian Walid Khalidi (1988) and a "blueprint for ethnic cleansing" by Israeli historian Ilan Pappé (2006, 86). In contrast, Israeli military historian David Tal (2004, 87) argues that while the plan did provide for the deportation of Palestinian residents and the destruction of their villages, this was not its raison d'être - rather, the primary purpose of establishing Jewish-Israeli territorial control was as a defensive safeguard in the event of invasion.

36. Sheikh Ra'ed Salah v. Minister of Interior, HCJ 4706/02, judgment, 17 July 2002.

37. 'Multilateral Treaties Deposited with the Secretary-General: Status as at 31 December 1991' UN Doc. ST/LEG/SER.E/10 (1992) 149.

38. See, e.g. UN Human Rights Committee, 'Concluding Observations: Israel', UN Doc. CCPR/C/ 79/Add.93, 18 August 1998, §4,11. Some international lawyers, such as John Quigley (1994), however, do question the procedural and substantive validity of Israel's derogation.

39. UN Human Rights Committee, "Concluding Observations: Israel", UN Doc. CCPR/C/79/ Add.93, 18 August 1998, $\S 11$.

40. UN Human Rights Committee, "Concluding Observations: Israel”, UN Doc. CCPR/CO/78/ ISR, 21 August 2003, $\S 12$.

41. Government of Israel, "Second Periodic Report to the Human Rights Committee", 20 November 2001, Addendum to UN Doc. CCPR/C/ISR/2011/2, 4 December 2001.

42. UN Human Rights Committee, "Concluding Observations: Israel”, UN Doc. CCPR/C/ISR/ CO/4, 21 November 2014, §10; UN Human Rights Committee, "Concluding Observations: Israel", UN Doc. CCPR/C/ISR/CO/3, 29 July 2010, $§ 5,7$.

43. Dr. Herzl Cook v. Defense Minister of the Provisional Government of the State of Israel, et al.; Ziborah Wienerski v. The Minister of Defense, et al., HCJ 1/48; 2/48, HaMishpat vol. 3, 1948; quoted in Jiryis (1976, 13-14).

44. Al-Karbutli v. Minister of Defence at al., HCJ 7/48, judgment, 3 January 1949.

45. Zeev v. The Acting District Commissioner of the Urban Area of Tel Aviv (Gubernik), HCJ 10/48; Leon v. Acting District Commissioner of Tel Aviv, HCJ 5/48.

46. El-Ard v. Commissioner of the Northern District, HCJ 39/64.

47. Al-Assad v. Minister of Interior, HCJ 2/1979.

48. Makhoul v. Jerusalem District Commissioner, HCJ 322/81.

49. The Association for Civil Rights in Israel (ACRI) v. The Knesset and the Government of Israel, HCJ 3091/99, judgment, 8 May 2012, paras. 7, 9, 11.

50. ACRI v. Israel, interim decision, 1 August 2006. 
51. ACRI v. Israel, interim decision, 1 August 2006.

52. ACRI v. Israel, interim decision, 7 December 2011.

53. ACRI v. Israel, judgment, 8 May 2012, para. 11.

54. ACRI v. Israel, judgment, 8 May 2012, para. 11.

55. Kahana v. The Minister of Defence, HCJ 1/80, PD 35(2), 253, 257.

56. ACRI v. Israel, judgment, 8 May 2012, para. 19.

57. ACRI v. Israel, judgment, 8 May 2012, para. 17.

58. For example, parts of Israel's 1973 emergency regulations relating to naval vessels were simply renamed and consolidated in permanent legislation in the form of the Shipping Law (Foreign Naval Vessel Under Israeli Control) 2005 and the Shipping Law (Violations Against the Security of International Sailing and Maritime Facilities) 2008.

59. Shany and Rosenzweig (2012), citing the 2008 Incarceration of Unlawful Combatants Law (Temporary Order and Amendment) enacted in anticipation of Operation Cast Lead.

60. The Association for Civil Rights in Israel, "Counter-Terrorism Bill: Undemocratic Emergency Regulations Could Become Permanent Law”, 4 August 2011.

61. Quoted in Lis, Jonathan. "Knesset Passes Sweeping Anti-terrorism Law" (Ha'aretz, 15 June 2016).

62. Adalah, "Israel's New Anti-Terror Law Violates Arab Citizens' Human Rights" (19 June 2016).

63. Within 24 hours of the legislation passing parliamentary approval, Israel's Minister for Public Security, Strategic Affairs and Information, Gilad Erdan, stated that "a price must be paid" by activists who support the Palestinian civil society call for boycott, divestment and sanctions (BDS) against Israel. Erdan said he has put together "a legal team that is working with the Israeli Justice Ministry to ensure that there is a price for boycott", implying that this team would seek to find connections between BDS activism and support for terrorism. Schaeffer Omer-Man, Michael. "Senior Israeli Minister: Make BDS Activists in Israel 'pay a price" (+972 Magazine, 16 June 2016).

64. Following the 2009 elections in Israel and the formation of a series of increasingly right-wing coalition governments under Benjamin Netanyahu - spanning the 18th Knesset from 20092013, the 19th Knesset from 2013-2015, and the 20th Knesset from 2015 on - "a flood of discriminatory legislation" was initiated which seek to dispossess and discriminate in various ways against Palestinian citizens of Israel. See Adalah's "Discriminatory Law Database" at http://www.adalah.org/en/law/index, which documents dozens of pieces of Israeli legislation already in force or at different stages in the legislative process.

65. Harkov, Lahav. "Terror Bill Passes into Law" (The Jerusalem Post, 15 June 2016).

66. “Israel's Knesset Passes 'Draconian' Anti-terrorism Law” (Ma’an News, 15 June 2016).

67. ACRI v. Israel, judgment, 8 May 2012, separate opinion of Chief Justice (Retired) D. Beinisch.

\section{Disclosure statement}

No potential conflict of interest was reported by the author.

\section{ORCID}

John Reynolds (D) http://orcid.org/0000-0002-0885-4460

\section{References}

Abu Hussein, Hussein, and Fiona McKay. 2003. Access Denied: Palestinian Land Rights in Israel. London: Zed Books.

Addameer. 2012. Palestinian Political Prisoners in Israeli Prisons. Ramallah: Addameer.

Agamben, Giorgio. 1995. Homo Sacer: Sovereign Power and Bare Life. Translated by Daniel HellerRoazen (1998). Stanford: Stanford University Press. 
al-Asmar, Fouzi. 1978. To Be an Arab in Israel. Beirut: Institute for Palestine Studies.

Bhandar, Brenna, and Rafeef Ziadah. 2016. "Acts and Omissions: Framing Settler Colonialism in Palestine Studies.” Jadaliyya, January 14.

Bisharat, George. 1994. "Land, Law, and Legitimacy in Israel and the Occupied Territories." The American University Law Review 43: 467-561.

B’Tselem. 1992. Detained Without Trial: Administrative Detention in the Occupied Territories Since the Beginning of the Intifada. Jerusalem: B'Tselem.

B’Tselem. 2002. Land Grab: Israel's Settlement Policy in the West Bank. Jerusalem: B’Tselem.

Cohen, Amichai, and Stuart Cohen. 2011. Israel's National Security Law: Political Dynamics and Historical Development. London: Routledge.

Dajani, Souad R. 2005. Ruling Palestine: A History of the Legally Sanctioned Jewish-Israeli Seizure of Land and Housing in Palestine. Geneva: Centre on Housing Rights and Evictions, and BADIL Resource Center for Palestinian Residency \& Refugee Rights.

Dugard, John, and John Reynolds. 2013. "Apartheid, International Law, and the Occupied Palestinian Territory." European Journal of International Law 24(3): 867-913.

Etkes, Dror, and Hagit Ofran. 2006. Breaking the Law in the West Bank: Israeli Settlement Building on Private Palestinian Property. Jerusalem: Peace Now.

Gregory, Derek. 2004. The Colonial Present. Malden, MA: Blackwell.

Gross, Emanuel. 2001. "Human Rights, Terrorism and the Problem of Administrative Detention in Israel: Does a Democracy Have the Right to Hold Terrorists as Bargaining Chips ?" Arizona Journal of International and Comparative Law 18(3): 721-791.

Gross, Oren, and Fionnuala Ní Aoláin. 2006. Law in Times of Crisis: Emergency Powers in Theory and Practice. Cambridge: Cambridge University Press.

Gunneflo, Markus. 2016. Targeted Killing: A Legal and Political History. Cambridge: Cambridge University Press.

Hofnung, Menachem. 1996. Democracy, Law and National Security in Israel. Brookfield, VT: Dartmouth.

Hussain, Nasser. 2007. "Hyperlegality.” New Criminal Law Review 10: 514-531.

Khalidi, Walid. 1988. "Plan Dalet: Master Plan for the Conquest of Palestine." Journal of Palestine Studies 18(1): 4-33.

Koskenniemi, Martti. 2005. From Apology to Utopia: The Structure of International Legal Argument. Reissue with a New Epilogue. Cambridge: Cambridge University Press.

Kretzmer, David. 1990. The Legal Status of the Arabs in Israel. Boulder: Westview Press.

Jabareen, Hassan. 2016. "Why 'Jewish and Democratic' Values Negate Palestinian Equal Rights." The Nakba Files, September 8.

Jayasuriya, Kanishka. 2008. "Struggle Over Legality in the Midnight Hour: Governing the International State of Emergency." In Emergencies and the Limits of Legality, edited by Victor V. Ramraj. Cambridge: Cambridge University Press.

Jiryis, Sabri. 1976. The Arabs in Israel. New York: Monthly Review Press.

Joseph, Bernard. 1948. British Rule in Palestine. Washington, DC: Public Affairs Press.

Lloyd, David. 2012. "Settler Colonialism and the State of Israel: The Example of Palestine/Israel." Settler Colonial Studies 2(1): 59-80.

Lustick, Ian. 1980. Arabs in a Jewish State: Israel's Control of a National Minority. Austin: University of Texas Press.

Makdisi, Saree. 2008. Palestine Inside Out: An Everyday Occupation. New York: W.W. Norton.

Masri, Mazen. 2017. The Dynamics of Exclusionary Constitutionalism: Israel as a Jewish and Democratic State. Oxford: Hart.

Mehozay, Yoav. 2012. "The Fluid Jurisprudence of Israel's Emergency Powers: Legal Patchwork as a Governing Norm.” Law \& Society Review 46(1): 137-166.

Mironi, Mordechai. 1986. "Back-to-Work Emergency Orders: Government Intervention in Labor Disputes in Essential Services." Mishpatim 15: 350-388.

Nakkara, Hanna Dib. 1985. "Israeli Land Seizure Under Various Defense and Emergency Regulations." Journal of Palestine Studies 14(2): 13-34. 
Ophir, Adi, Michal Givoni, and Sari Hanafi. 2009. "Introduction.” In The Power of Inclusive Exclusion: Anatomy of Israeli Rule in the Occupied Palestinian Territories, edited by Adi Ophir, Michal Givoni, and Sari Hanafi. New York: Zone Books.

Pappé, Ilan. 2006. The Ethnic Cleansing of Palestine. Oxford: Oneworld.

Peres, Shimon. 1962. "Military Law is the Fruit of Military Governance." Davar, January 26.

Peretz, Don. 1991. “Early State Policy Towards the Arab Population, 1948-1955." In New Perspectives on Israeli History: The Early Years of the State, edited by Laurence J. Silberstein. New York: New York University Press.

Quigley, John. 1994. “Israel's Forty-Five Year Emergency: Are There Time Limits to Derogations from Human Rights Obligations?” Michigan Journal of International Law 15: 491-518.

Quigley, John. 2005. The Case for Palestine: An International Law Perspective. 2nd ed. Durham: Duke University Press.

Reynolds, John. 2010. "The Use of Force in a Colonial Present, and the Goldstone Report's Blind Spot.” Palestine Yearbook of International Law 16: 55-77.

Reynolds, John. 2017. Empire, Emergency and International Law. Cambridge: Cambridge University Press.

Said, Edward. 1979. The Question of Palestine. New York: Times Books.

Shafir, Gershon. 1989. Land, Labor and the Origins of the Israeli-Palestinian Conflict, 1882-1914. Cambridge: Cambridge University Press.

Shany, Yuval, and Ido Rosenzweig. 2012. "High Court of Justice Rejects Petition to End Israel's State of Emergency." Terrorism \& Democracy 41, May.

Shehadeh, Raja. 1993. The Law of the Land: Settlement and Land Issues Under Israeli Military Occupation. Jerusalem: PASSIA.

Shetreet, Simon. 1984. "A Contemporary Model of Emergency Detention Law: An Assessment of the Israeli Law." Israel Yearbook on Human Rights 14: 182-220.

Strawson, John. 2002. "Reflections on Edward Said and the Legal Narratives of Palestine: Israeli Settlements and Palestinian Self-Determination.” Penn State International Law Review 20(2): 363384.

Strawson, John. 2005. "British (and International) Legal Foundations for the Israeli Wall: International Law and Multi-Colonialism." Palestine Yearbook of International Law 13: 1-26.

Tal, David. 2004. War in Palestine, 1948: Strategy and Diplomacy. London: Routledge.

Vagts, Detlev F. 2001. "Hegemonic International Law." The American Journal of International Law 95: 843-848.

Weizman, Eyal. 2007. Hollow Land: Israel's Architecture of Occupation. London: Verso.

Zureik, Elia T. 1979. The Palestinians in Israel: A Study in Internal Colonialism. London: Routledge. 